\title{
Adopting Continuing Personal and Professional Development To Improve Quality of Teaching (Personal Experience)
}

\author{
Derar Eleyan, Amna Eleyan \\ Faculty of Information Technology, Birzeit University, Palestine \\ deleyan@birzeit.edu \\ aeleyan@birzeit.edu
}

\begin{abstract}
:
Quality of teaching is an essential issue in developing a significance academic quality. Continuing personal and professional development is a procedure of improving teaching quality. It helps the teacher to spot weakness in teaching and helps her/him to adopt and develop individual learning plan to overcome these weakness. It also improves the teacher subject knowledge. This paper introduced the different teaching theories to follow in the teaching process and how these theories affect positively personal teaching experience. The paper also recommends the adoption of the process of continuing professional and developing program to create a new culture of personal development through accepting observations from line manager or colleagues to raise strengths and weaknesses of teaching and consequently improve the quality of teaching and then improve the academic quality.

Keywords: teaching theories, professional development, observation, reflective journal, models of reflections.
\end{abstract}

\section{Introduction}

This paper focuses on the importance of adopting a portfolio of personal and professional development as a teacher in the education institutions. This portfolio is divided into three sections. The first section is about the personal and professional development in England (South East Essex College of Arts and Technology) which is accredited by the University of Essex showing my role and responsibilities as a teacher and which educational theories are used to enrich teaching experience?

The second section is about the influence of personal perspective including my thoughts on learning and teaching and how these influenced on my personal and professional development. The final part is about a range of the mechanism for my personal and professional development including the reflective journal on three of my experiences in learning and teaching. 


\subsection{Problem Statement}

Academic quality in the higher education institution is always of high concern. Teacher is an essential asset in the teaching and learning process. Developing a high level of academic quality requires paying more attention to this component as good teachers produce good students and therefore assure high level of academic quality. How to improve the teacher quality is the main concern of this paper.

\subsection{Research methodology}

This research is used different ways of improving the teacher quality. Literature review is the first research method used to find out from the literature qualities of good teacher and what are the different teaching methods to follow in order to improve the teaching and learning process and therefore raise the level of academic quality. Student's feedback is an important source of information where the teacher can find positive and negative feedback. This feedback will be as a driver to spot weaknesses and how to overcome and improve them. Observations from line manager or colleagues are also a good source of gaining feedback about the teaching process. The observation should be conducted from a professional and experienced staff. Also selfevaluation, the teacher can follow to spot weaknesses by performing a form of reflective journal.

\section{Literature Review}

\section{A. Personal and Professional Development in Work-based experience Context}

\section{Teaching roles and contexts in the lifelong learning sector in UK.}

Lifelong learning in the LLUK has identified two distinct teaching roles in the Lifelong Learning Sector [2] as follow:

$>$ A full teacher role which represents the full range of responsibilities performed by those who are expected to attain the status of Qualified Teacher, Learning and Skills (QTLS).

$>$ An associate teacher role which contains fewer teaching responsibilities and which be performed by those who are expected to attain the status of Associate Teacher, Learning and Skills (ATLS). Research undertaken by LLUK indicates that all teachers undertake the same activities in relation to the teaching cycle, these activities are:

$>$ Initial assessment, 
$>$ Preparation and planning

$>$ Delivery

$>$ Assessment

$>$ Evaluation

$>$ Revision based on evaluation.

The teacher should have three essential qualities, which make him/her a good teacher and leave a positive influence on learners [14].

$>$ Back ground knowledge

$>$ Professional skills

$>$ Personal qualities

\section{Personal Qualities Associated with Teaching Subject knowledge}

$>$ Confidence

$>$ Understanding

$>$ Empathy

$>$ Attentive Listening

$>$ Genuineness

$>$ Ability and eagerness to help

$>$ Fairness

Awareness of "rules" under which tutoring is delivered.

\section{Professional skills Associated with Teacher [7]}

$>$ planning and organizing

$>$ communication skills

$>$ problem-solving

$>$ presentation skills

$>$ determination and initiative

$>$ thoroughness and attention to detail

$>$ leadership and teamwork

$>$ creativity

$>$ patience and understanding

$>$ health and physical fitness

$>$ scientific, mathematical or other subject knowledge

$>$ technical expertise, especially information and communications technology (ICT)

$>$ training and instruction skills.

$>$ enthusiastic 


\section{B. Educational Theories}

\section{Bloom's Taxonomy}

Benjamin Bloom identified three domains of educational activities [4]:

a. Cognitive: mental skills (Knowledge)

The cognitive domain involves knowledge and the development of intellectual skills. This includes the recognition of specific facts, procedural patterns, and concepts that serve in the development of intellectual abilities and skills.

b. Affective: growth in feelings or emotional areas (Attitude)

This domain includes the manner in which we deal with things emotionally, such as feelings, values, appreciation, enthusiasms, motivations, and attitudes.

c. Psychomotor: manual or physical skills (Skills)

The psychomotor domain includes physical movement, coordination, and use of the motor-skill areas. Development of these skills requires practice and is measured in terms of speed, precision, distance, procedures, or techniques in execution.

\section{The Experiential Theory of Learning}

Many courses in HE are divided into theory and practice. The theory may be taught didactically through classroom lectures while practice are acquired through simulated work-placed practice and workshop projects[3].

Kolb developed the Learning Style Inventory to help learners understand their strengths and weaknesses. The inventory measures the learner's preferences in the four stages learning. These four stages are shown in Figure 1 [1]

\section{a. Abstract Conceptualization [1]:}

"In this stage, learning involves using logic and ideas, rather than feelings to understand problems or situations. Typically, you would rely on systematic planning and develop theories and ideas to solve problems."

\section{b. Active Experimentation [1]:}

"Learning in this stage takes an active form - experimenting with, influencing or changing situations. You would take a practical approach and be concerned with what really works..." 


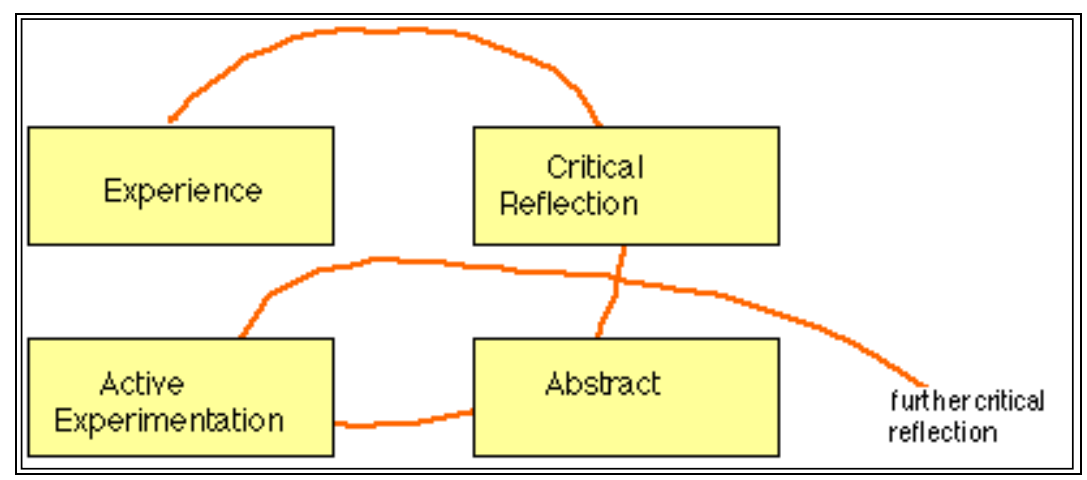

Figure 1. Kolb's four-stage of Experiential Learning

\section{$>$ Humanistic Theory of Learning}

This theory concerns of human growth, motivation and potential. Maslow developed a theory of Human Motivation that concentrated of the affective domain and how "learners attempts to take control of their own life processes". Maslow's hierarchy of motivation contains five levels. The four levels (lower-order needs) are considered physiological needs, while the top level is considered growth needs. The lower level needs need to be satisfied before higher-order needs can influence behavior [5]. The levels are as follows [5].

Self-actualization - morality, creativity, problem solving, etc.

Esteem - includes confidence, self-esteem, achievement, respect, etc.

Belongingness - includes love, friendship, intimacy, family, etc.

Safety - includes security of environment, employment, resources, health, property, etc.

Physiological - includes air, food, water, sex, sleep, other factors towards homeostasis, etc.

\section{$>$ Behaviorist Theory of Learning}

The theory of behaviourism concentrates on the study of obvious behaviours that can be observed and measured.

Here are some principles that Skinner identified in his research [11]:

-Pleasant experiences (such as rewards or praise) are positive reinforces. They cause learners to make desired connections between stimuli and responses.

-Unpleasant experiences (such as punishment) are negative reinforces. They cause learners to avoid undesirable responses to stimuli.

-Continuous reinforcement increases the rate of learning.

- Irregular reinforcement contributes to longer retention of what is learned.

-Both positive and negative reinforcement can shape behavior.

-A lack of any reinforcement can also shape behavior. If people receive no acknowledgement of their behavior, they will change that behavior until they receive some kind of reinforcement. 


\section{c. Teaching Experience}

\section{South East Essex College of Arts and Technology (SEEC)}

The first teaching role I have achieved is in SEEC. This college is located in Southend on Sea, Essex and it is accredited from Essex University to run degree courses in Networking, Internet Technology and Computing. I have been working also as a course team leader in computing and supervising the final year projects. Additionally, I have taught the following courses:

$>$ Data Base Management Systems

$>$ Internet Applications

$>$ Data Mining

$>$ Information Systems

\section{Personal and Professional Development in the College}

My role in the college is a lecturer in Computing and Internet Technology. I need to apply educational theories, teaching and learning strategies, assessment methods, evaluation and reflection. Also, I need to demonstrate how to be a good teacher by developing my personal qualities and professional skills. So, my role is to implement the teaching and learning theories that I have learned from PGDE course in a practical way.

I have developed my Personal and Professional skills during my teaching as in the following:

$>$ I have a good knowledge and understanding in my subject. This is because I have a PhD in Information Systems.

> I am confident of my CIS subject because I prepared everything related to that subject by myself. I keep up-to-date with the latest version of software applications and consider that in the curriculum development and materials/handouts preparing.

$>$ I understand my learners' abilities and consider the differentiation level among the students when preparing the material. The outcomes of each lesson cover both the easy/basic material and the advanced. Also, I explain the new concepts by giving an easy example from the real life.

$>$ I start and end a lesson in time because of good organization and planning.

> I am patient. I recap the information after explaining each outcome and ask open questions to specific students. This is to assure that the students understand the outcomes of the lesson.

$>$ I enjoy teaching and enthusiastic in my subject. I always show my students the values behind the items I am teaching in an exciting and friendly way.

$>$ I explained the health and safety issues when I started teaching CIS course. Health and Safety regarding how to use the computer (switch on/off).

$>$ At the end of each session, I deliver a student feedback sheet in order to know their opinion/feedback of that session. Also, I do self-evaluation and reflection in order to improve my performance and update myself. 
> I improve my literacy, numeracy and ICT skills by preparing action plan. Regarding to literacy, I prepare well before starting the lesson by checking the words spelling in the handouts and on the white board.

$>$ I always praise the students and encourage them.

\section{Educational Theories}

\section{The Experiential Theory of Learning}

I adopt the experiential theory because it is effective and suitable for students' level. The students reinforce their knowledge by practicing their skills using the computer.

My course was divided into theory and practice. I explained the theoretical aspects of the session through classroom lectures. Then let the students implement the theoretical aspects practically through doing exercises, assignments and projects via workshops. This assures that the students understand the outcomes of the course. Within each session, I gave the students an exercise to practice after explaining the related theoretical concepts. I deliver assignments after finish explaining the related subjects in course. At the end of course, I deliver project that covers the significant aspects of the subjects. These practical skills are assessment methods that measure the students' understanding.

\section{The Humanistic Theory of Learning}

I consider this theory in my teaching in order to motivate my students. I respect my students and treat them friendly. I always praise and encourage them to feel confident, self-esteem and contribute in the class effectively.

\section{The Behaviourist Theory of Learning}

Behavioural theories of learning include both positive and negative reinforcement. The main principle of the use of positive reinforcement is to increase the desired behaviour changes in the classroom. One of the most teaching behaviour I employ is asking open questions. Questions are directed at the whole class or individuals. When the student answers a question with a partially correct response, I picked up the correct aspect of the answer and praise him/her to reinforce the student's contribution. So, I respond to student success rather than failures. However, the negative reinforcement is related to the disruptive behaviour when peers talking with each other. If this occur, I can't do any punishment because my learners are adults, but I stop talking for few minutes, look at the students until stop talking then I tell them if they need any query let me know rather than talking to each other. Also, for those students who are not attending all the classes, I tell them about the policy of the college that if any one missed more than three times without any excuse, he/she will be automatically withdrawn from the course.

During my teaching in the college, I have gained fruitful ideas and information about teaching and learning techniques, how to understand my learners' abilities in order to meet their needs, assessment methods, self-reflection and evaluation, design and develop a curriculum. However, what I gained from PGDE course and teaching in the college is a starting point for the future career 
as teaching and learning is an on-going process. I need to keep up-to date with my subject specialist such as what is the latest version of software available in the market and what are the market needs. I need to improve subject knowledge by continuing reading using different resources (books, articles Web sites), attending advanced course if needed to improve my skills and discuss with peers who are more expertise in these fields.

\section{The Influence of Personal Perspective}

I have no teaching experience before I commenced PGDE course. I thought that to be a good teacher, it is enough to have good subject knowledge and understand what you are teaching. But, when I involved in PGDE, I have realised that to be subject specialist is not enough, I must have knowledge about teaching and learning including both theoretical and practical aspects. I got lots of teaching experience starting from micro teaching as part of the PGDE through my teaching in the college. The constructive feedbacks, which I got from my tutor and observer helped me to identify strengthens and weaknesses. These feedbacks played a vital role in improving my teaching and learning strategies and skills and developing my personal and professional skills.

A. Micro Teaching

The first time I delivered a session was in microteaching, I selected a topic related to my subject experience "Introduction to Computer" and I considered the differentiation level of the learners. So, the material started from simple concept up to the advanced one. I prepared lesson plan and used various assessment methods: Question/Answer, Discussion and Practical assignment. I used many resources: Handouts, Interactive White Board, and PowerPoint and Hardware components for demonstration. I prepared well for the micro teaching and I was confident of my subject. However, I was worried about how to stand in front of the learners and deliver a lesson, this feeling made me nervous. I got constructive feedback from my tutor and the learners. The strengthens include:

$>$ The material is well and clear structured.

$>$ Aims and objectives are clearly defined.

$>$ The learners are engaged in the class by asking them open questions.

The weaknesses include:

$>$ My voice volume is lower than needed which makes the learners on the back can't hear me clearly.

$>$ I asked questions to whole class. It would be effective to ask questions to specific learners and repeat the answer to whole class.

$>$ I stayed standing in front of learners all the session time. It is better to walk through the class not just stick in my position.

$>$ I delivered the session less that the target time by 4 minutes.

From the above feedback, I need to develop my personal and professional skills as the following: 
$>$ Make my voice volume louder that all learners can hear me clearly.

$>$ Engage the learners with a group work.

$>$ Must ask open questions to specific students.

$>$ Walk through the class not just stick in my position.

$>$ Show all the learners the hardware components and how to be connected by calling them all into one table. This allows learners to move from their desks and not feel bored.

$>$ Must be commitment to the lesson plan and deliver the session limited to the time target.

I have done an action plan (See Appendix A.1) that addresses the above weaknesses in order to improve my performance.

B. Class Observation

Each semester in the college, every teacher is evaluated once each semester. Each evaluation includes an observation performed by the dean faculty and his assistants. My first observation raised both weaknesses and strengths in my teaching lesson.. The positive feedback includes the following strengths:

$>$ Subject knowledge

$>$ Lesson plan is well written in details.

$>$ Aims and objectives are clear and correspond to teaching and learning strategies.

$>$ Instruction given clearly and repeated for reinforcement

$>$ Enthusiasm for subject

The weaknesses include:

$>$ Need to prepare the handouts before starting the lesson

$>$ Must start the class on time and give the break on time as the session observed is of three hours long.

$>$ Must refer to the handouts and use them in teaching.

$>$ Need to ask open questions to specific student.

$>$ Check the spellings.

It was useful feedback that I must prepare everything before starting the lesson, use the handouts effectively and be punctual. I prepared an action plan (see Appendix A.2) that stated the area of developments and the target to improve these developments which would be next observation. This action plan helped me to avoid repeating the weaknesses in the next observation.

In the second observation, I got the following positive and negative feedback. The positive feedback

$>$ Effective planning

$>$ Well organised handouts

$>$ Ask specific question to specific student.

$>$ Patience in repeating and checking progress issues

$>$ Confident grasp of subject knowledge

The negative feedback: 
$>$ Check spelling in handouts and board

$>$ Developing different teaching strategies

$>$ Finish the lesson on time.

I have improved my performance in that I prepared the handouts before starting the lesson, referred to the handouts in teaching, went around the students while practicing to help them and ask specific questions to specific students to assure they understand the lesson. I started the lesson on time but finished it five minutes over the required time. I still need to spell check the words before writing them on the board. The action plan for this observation is seen in Appendix A.3.

\section{The Mechanisms for Personal and Professional Development}

\section{A. Reflective Journal}

A reflective journal could be used both a diary and a log and be used to "... record and reflect upon incidents and experiences from which something useful can be learnt that will help us to develop and enhance our professional practice"[15]. Reflective journal is an assessment tool that designed to encourage reflective, self-directed learning. I have recognised the teaching and WBE placement. The reflection includes my strengths and weaknesses which are based on my tutor feedback and my critical thinking. Also, it includes the mechanisms such as ILP and action plans in order to improve the weaknesses in the future. The reflective journal is also important in improving my personal and professional developments. Therefore, I reflected on my performance after doing micro teaching.

\section{B. Models of Reflection}

Reflection is a metacognitive strategy to help individuals or organizations reflect upon experiences, actions and decisions taken. A practitioner engages in reflection when problem in practice arises and an attempt is made to understand and resolve it.

Reflection is a cyclical stage process and many stage process models of reflection have been proposed to be used as metacognitive tools. The models all share some variation of three basic stages: experience (the event and feelings toward it), a critical analysis of the situation and any new knowledge gained, development of new perspectives and strategies to apply in the future.

This section provides a brief description of some of the reflective models.

\section{Reflective Model [13]}

A visual model for teacher reflection has been adapted from the works of Sparks-Langer [13]. This model understands the interaction of dispositions (being), practice (doing), and professional knowledge (knowing). 
The model of reflection contains five categories of knowledge. The professional knowledge bases are located on the right of the diagram. They include knowledge of self as teacher, knowledge of content, knowledge of teaching and learning, knowledge of students, and knowledge of school and societal contexts. These knowledge bases are essential for what prospective teachers should know and be able to do. On the left of the diagram is the "doing" dimension of teacher behaviour. It identifies performance related to the planning, implementing (action plan), and evaluating.

This model integrates theory with practice by asking the following significant questions in the context of classroom and field experiences.

Exploring Teaching-- "Shall I Teach?"

Academic Preparation-- "What Shall I Teach?"

Understanding Learners-- "How Do Students Learn?"

Organizing for Teaching --"How Shall I Teach?"

Schooling and Cultural Context--"Why Do We Teach?"

\section{Schon Reflective Practice [9].}

Donald Schon introduced the concept of reflective practice, which consists of strategies of action, understanding of phenomena, ways of framing the situations encountered in day-to-day experience. Schon's framework of reflection-in-action and reflection-on-action involve the idea of professional practice based upon knowing-in-action and knowledge-in-action derived from the construction and reconstruction of professional experience. This reflection-in-action may take the form of problem solving, theory building, or re-appreciation of the situation. Reflective practice involves thoughtfully considering one's own experiences in applying knowledge to practice while being coached by professionals in the discipline[9]; [10].

Reflective practice is also a reflection process for developing administrators' expertise in problem solving, decision-making, and complex thinking. The learning process in reflective practice begins with the examination of an individual's own actions and contrasting the actions to the ideal of the practice. The process results in behavioural changes that improve professional performance [6].

\section{Greenaway 3-stage model [8].}

Based on a simple 3-stage experiential learning cycle the Greenaway model suggests a Plan>>Do>>Review>> cycle as shown in Figure. 2. 


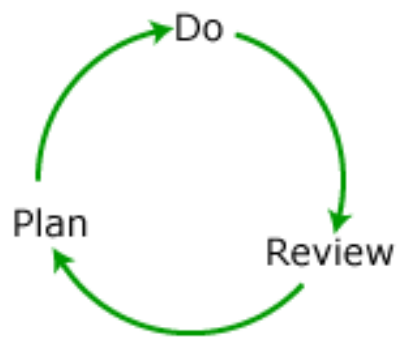

Figure. 2 Gibbs' reflective cycle [8]

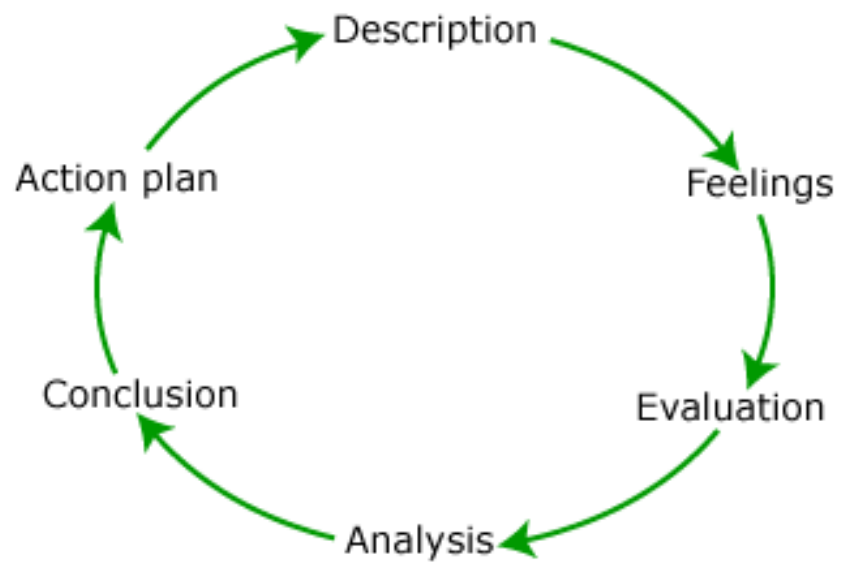

Figure. 3 Structured reflection based on Kolb's Learning Cycle [8].

A model based directly on Kolb's experiential learning cycle where active experimentation leads to a transfer of learning from current cycle to a new cycle.

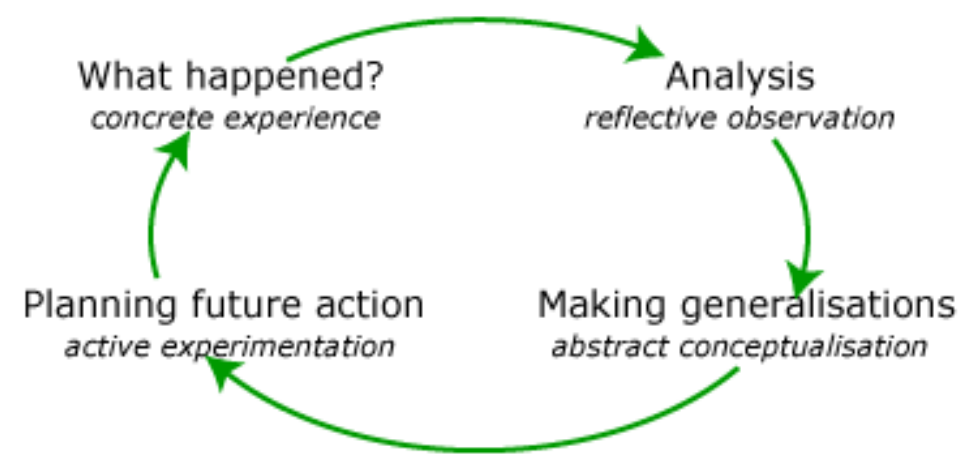




\section{Reflection on Three Experiences}

The following describe and analyse the reflection of the three significant experiences from my learning journal.

\section{Micro-Teaching}

This section provides details about microteaching session including tutor's and students' feedback. Micro-teaching was a new experience and I wrote my feeling before in the reflective journal during the session planning:

"This is the first time I will stand in front the students and deliver a session. It is obvious I would be nervous but I have to involve in that experience in order to be a quality and professional teacher. I need to prepare well the material by considering my students backgrounds and time limitation. The handouts must be clear and easy to understand. I need to engage the students by asking them open questions. I need to use assessment methods"

After doing the micro-teaching, I wrote the following in the reflection journal:

"I was nervous in the first two minutes, but after that I felt relax when start asking the students questions and realised that they were interested in my subject. At the end, I got constructive feedback from my tutor and students. All the feedbacks from the students were positive which made me confident. My tutor feedback includes both strengthens and weaknesses. My tutor feedback was very useful that enabled me to know my weaknesses and try to overcome them in the future". From my tutor feedback, I need to develop my personal and professional skills as the following:

$>$ Make my voice volume louder.

> Use different teaching strategies. For example, Show all the learners the hardware components and how to be connected by calling them all into one table. This allow learners to move from their and not feel bored.

$>$ Be punctual.

I have done an action plan to improve my performance and personal and professional skills as shown in Appendix A.1.

\section{a. First Observation}

This section provides details about the first observation in college.

I wrote my feeling in the journal reflection before the first observation:

"This is the first observation and I was concern not to repeat the weaknesses that happened in the previous micro-teaching. I am teaching in a community centre and the students are beginners in ICT and not commitment. I don't have resources to deliver the session, only white board. The situation would be challenge."

After doing the session: 
"I didn't manage to prepare the handouts before starting the session which leads to start the lesson late by 10 minutes. Many students came late and distracted the class. It was challenging, but I managed to attract their attention. I must give the students break after one hour, but I didn't. "

From my observer feedback, I need to develop my personal and professional skills as the following:

$>$ Need to prepare the handouts before starting the lesson.

> Must use the lesson plan effectively; start the class on time and give the break on time.

$>$ Need to provide large and clear graphs and refer to them in teaching.

$>$ Need to ask open questions to specific student.

The action plan is shown in Appendix A.2.

\section{b. Second Observation in the college}

This section provides details about the final observation in WBE placement.

I wrote my feeling in the journal reflection before the last observation:

"This is the last observation and I must not repeat the weaknesses that happened in the previous observations. I need to use different teaching strategy in order to engage my students. I will use a matching game that matching the outcomes with the subjects covered in the previous sessions."

After doing the session:

"The (matching game) teaching strategy was effective. My students were completely engaged and they liked and enjoyed it. I praised my students by saying well done, and clapping hands. My observer was happy of my performance."

From my observer feedback, I need to develop my personal and professional skills as the following:

$>$ Continue to develop alternative teaching strategies

$>$ Check spelling on handouts and white board

$>$ need to work on timing estimation in planning

The action plan is shown in Appendix A.4.

\section{a. Reflection Journal Related to Models of Reflection}

My reflection journal includes reflection before delivering the session and reflection after doing the session. Reflection before delivering the session includes knowing my student, prepare well for the subject, and use suitable assessment methods. Reflection after doing the session by filling selfevaluation sheet, which includes the following questions:

1. What is done well?

2. What is done less well?

3. How to improve it?

After defining the weaknesses, I use action plan in order to overcome these weaknesses and assign the target time for that.

My reflection is similar to Sparks-Langer model in that it is the interaction of being, doing (practice) and knowing (professional knowledge). Also, the questions asked (see Section 3.2.1) by that model 
which integrates theory with practice are considered in my reflection. For example, "Shall I Teach?", "What Shall I Teach?", "How Shall I Teach?".

My reflection is similar to Schon model in that "reflection -on-action", which I reflection is done after delivering the session.

My reflection is similar to Greenaway 3-stage model, Gibbs and Kolb in that their reflection is a cycle (on-going process) of planning, doing, analysing, evaluating and implementing by action plan.

\section{Conclusion and Recommendations}

This paper concludes that having a teaching qualification for teachers contribute positively and improve their teaching quality which also improves the quality throughout the institution. New legislations should be implemented and be part of the employment as what is now becomes as a condition of employment in UK for every teacher he should have a teaching qualification (PGDE) or promise to have them within two years of commencing teaching. Also adopting a procedure of implementing observations as part of teacher evaluation will also contribute positively to the quality and teaching for both teachers and the institution also adopting a CPD program within the faculty and ask every staff member to prepare and deliver at least two seminars on his experience or in a good practice in teaching and how to utilise the emerging techniques to improve the quality of teaching also he/she should attend workshops training courses delivered internally or externally to improve the knowledge experience and how to use different teaching techniques suitable for specific subject than the other.

\section{Appendix A}

\section{A.1 Micro Teaching}

\section{Initial Personal Development Plan}

Remember that this is a working document; return to it, update your action plan and review your progress and targets. 


\section{NAME: Derar Eleyan \\ DATE OF PLAN: 11/10/2008}

1. Following the feedback on your micro-teaching, what current skills and strengths have been identified?

I used PowerPoint slides (Handouts) and interactive white board to present the session material. Aims and objectives are clear and the handouts are well structured. I used different assessment methods: Q/A and practical assignment. I summarised the outcomes at the end of the session and gave brief introduction about the next session. I engage the learners by asking them effective questions.

2. Following the feedback on the micro-teaching, what development points have been identified?

$>$ My voice volume is lower than needed which makes the learners on the back can't hear me clearly.

$>$ I asked questions to whole class. It would be effective to ask questions to specific learners and repeat the answer to whole class.

$>$ I stayed standing in front of learners all the session time. It is better to walk through the class not just stick in my position.

$>$ I delivered the session less that the target time by 4 minutes

4. Having completed the personal audit, and completed your micro-teaching, what are your main priorities in terms of your personal and professional development?

\section{Personal:}

Must make my voice louder that all learners can hear me clearly. I need to praise the students who answer questions and repeat the answer to whole class. Must not be nervous and be relax when deliver the session.

\section{Professional - (teaching and learning):}

Must motivate and engage the students when demonstrating the hardware components by calling them around the table. This dynamic technique avoid the students to get bored.

\section{General:}

I must be more enthusiastic and use more teaching techniques to engage the learners.

What are your main concerns at this moment?

To learn from my mistakes in order to avoid them in the future.

\section{Action Plan-Micro Teaching}




\begin{tabular}{|c|c|c|c|c|}
\hline Development Need & Action Required & Resources/Support & $\begin{array}{c}\text { Evidence of } \\
\text { achievement will } \\
\text { be..... }\end{array}$ & Target Date \\
\hline Time management & $\begin{array}{l}\text { Need to assign the } \\
\text { expected time for each } \\
\text { outcome effectively in } \\
\text { the action plan } \\
\text { Use different teaching } \\
\text { techniques to engage } \\
\text { and motivate students } \\
\text { such as developing } \\
\text { group dynamic }\end{array}$ & $\begin{array}{l}\text { Lesson plan. Read } \\
\text { literature resources about } \\
\text { time management. } \\
\text { Discuss with my tutor and } \\
\text { peers. } \\
\text { Read PGDE handouts } \\
\text { related to teaching and } \\
\text { learning techniques. }\end{array}$ & $\begin{array}{l}\text { WBE placement } \\
\text { observations and } \\
\text { feedback. } \\
\text { WBE placement and } \\
\text { observation }\end{array}$ & $\begin{array}{l}\text { First WBE } \\
\text { observation } \\
\text { and feedback. } \\
\text { First WBE } \\
\text { observation } \\
\text { and feedback. }\end{array}$ \\
\hline
\end{tabular}


Action Plan- First Observation

\begin{tabular}{|c|c|c|c|c|}
\hline $\begin{array}{l}\text { Areas for } \\
\text { development }\end{array}$ & Action required & Resources/support & $\begin{array}{l}\text { Evidence of } \\
\text { achievement will be }\end{array}$ & Target Date \\
\hline $\begin{array}{l}\text { Prepare for the } \\
\text { session }\end{array}$ & $\begin{array}{l}\text { Prepare the } \\
\text { handouts before } \\
\text { start the session }\end{array}$ & $\begin{array}{l}\text { Print the handouts } \\
\text { before a day of the } \\
\text { coming session }\end{array}$ & $\begin{array}{l}\text { Prepare for the next } \\
\text { session and print out the } \\
\text { handouts for the next } \\
\text { observation. }\end{array}$ & $10 / 04 / 08$ \\
\hline $\begin{array}{l}\text { Commitment to } \\
\text { the lesson plan }\end{array}$ & $\begin{array}{l}\text { Start the lesson on } \\
\text { time and finish on } \\
\text { time }\end{array}$ & $\begin{array}{l}\text { Estimate the time } \\
\text { required to deliver each } \\
\text { objective in order to } \\
\text { finish on time. } \\
\text { Prepare well for the } \\
\text { session before on day } \\
\text { so that to start the } \\
\text { session on time }\end{array}$ & $\begin{array}{l}\text { Doing another } \\
\text { observation and } \\
\text { compare the results to } \\
\text { assure that the target } \\
\text { has been achieved. }\end{array}$ & $10 / 04 / 08$ \\
\hline Literacy & $\begin{array}{l}\text { Check the spelling } \\
\text { of the words } \\
\text { before writing it on } \\
\text { the board }\end{array}$ & $\begin{array}{l}\text { Need to prepare well for } \\
\text { the session and check } \\
\text { the spelling in the } \\
\text { handouts }\end{array}$ & $\begin{array}{l}\text { Doing typing and } \\
\text { printing exercises by } \\
\text { using Microsoft Word } \\
\text { Processor application. }\end{array}$ & $10 / 04 / 08$ \\
\hline $\begin{array}{l}\text { Teaching strategy } \\
\text { for drawing } \\
\text { handouts }\end{array}$ & $\begin{array}{l}\text { Print out large } \\
\text { handout for slides } \\
\text { contain pictures }\end{array}$ & $\begin{array}{l}\text { Select option Slides } \\
\text { instead of Handouts } \\
\text { when print out slides } \\
\text { using PowerPoint } \\
\text { software }\end{array}$ & $\begin{array}{l}\text { Printing large pictures } \\
\text { next observation }\end{array}$ & $10 / 04 / 08$ \\
\hline $\begin{array}{l}\text { Teaching strategy } \\
\text { for Using } \\
\text { Handouts }\end{array}$ & $\begin{array}{l}\text { To refer to the } \\
\text { handouts while } \\
\text { explaining the } \\
\text { outcomes of the } \\
\text { session }\end{array}$ & $\begin{array}{l}\text { Ask the student to open } \\
\text { certain page and look at } \\
\text { certain slide. This } \\
\text { enable the learners to } \\
\text { understand effectively }\end{array}$ & $\begin{array}{l}\text { Refer to the handouts in } \\
\text { the next observation }\end{array}$ & $10 / 04 / 08$ \\
\hline
\end{tabular}




\section{A.3 Second Personal Development Plan}

\section{Interim Personal Development Plan}

Remember that this is a working document; return to it, update your action plan and review your progress and targets.

\section{NAME: Derar Eleyan \\ DATE OF PLAN: 10/4/2008}

1. Following the feedback from the teaching and learning observations, what current skills and strengths have been identified?

$>$ Effective planning

$>$ Well organised handouts

$>$ Patience in repeating and checking progress issues

$>$ Confident grasp of subject knowledge

2. Following the feedback from your teaching and learning observations, what development points have been identified?

$>$ Check spelling in handouts and board

$>$ Developing different teaching strategies

$>$ Develop lesson timing

3. Which development points have been addressed since recording your previous PDP?

Personal:

> I low my voice and explain bit slowly because my learners are ESOL level.

$>$ I always motivate, encourage and praise my students.

> I am patience by doing recap and repeat the information for reinforcement.

(Professional) teaching and learning:

$>$ I use different assessment methods such as exercise and quiz.

$>$ I ask open questions to specific students.

$>$ I print out large pictures "screen shot" so that the students can see it clearly and relate the handouts to Microsoft Word Screen.

\section{General}

I understand my learners' abilities. I always write the new technical terms on the white board and explain it by giving an example from real life.

4. Following the feedback from your assignments: What development points have been identified?

$>$ Proof reading and spell check.

$>$ Refer to handout while covering the outcomes of the session. 
$>$ Go around the students while implementing an exercise on the computer and help them.

5 . What are your priorities in terms of your personal and professional progress at this stage?

$>$ Developing a more relaxed relationship with students.

$>$ Lesson plan and time management 
Action Plan-Interim Observation

\begin{tabular}{|c|c|c|c|c|}
\hline Development Need & Action Required & Resources/Support & $\begin{array}{l}\text { Evidence of achievement } \\
\text { will be..... }\end{array}$ & Target Date \\
\hline $\begin{array}{l}\text { Grammar and spelling } \\
\text { errors in handouts and } \\
\text { white board } \\
\text { Teaching Strategies }\end{array}$ & $\begin{array}{l}\text { Check grammar and } \\
\text { spelling errors using spell } \\
\text { check Tool in Microsoft } \\
\text { Word and PowerPoint. } \\
\text { Prepare well and check the } \\
\text { spelling of each word before } \\
\text { writing them on the white } \\
\text { board } \\
\text { Use different teaching } \\
\text { strategies to engage the } \\
\text { students and be motivated. } \\
\text { Allocate the expected time } \\
\text { required to finish each } \\
\text { outcome on the lesson plan } \\
\text { considering learners' } \\
\text { abilities. }\end{array}$ & 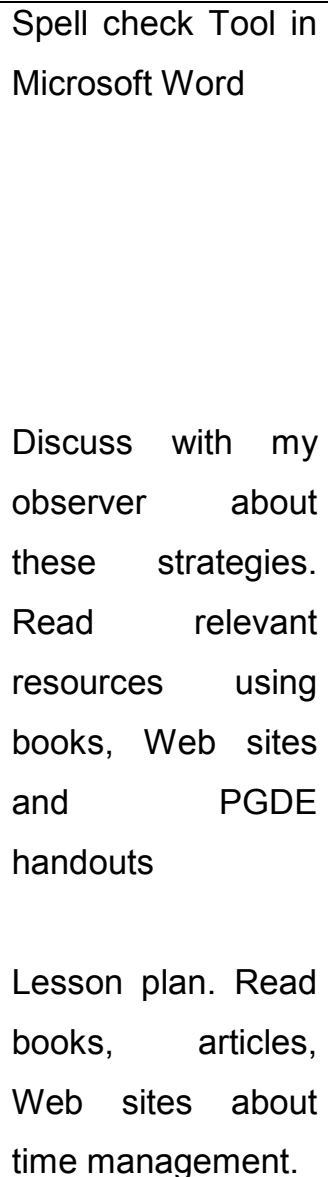 & $\begin{array}{l}\text { observation } \\
\text { observation }\end{array}$ & $28 / 04 / 2008$ \\
\hline
\end{tabular}


Final Personal Development Plan

\section{NAME: Derar Eleyan}

\section{DATE OF PLAN: $\quad 14 / 05 / 2008$}

1. Read through all the feedback from the assignments that you have completed and summarise your strengths and weaknesses in terms of your ability to present information and write analytically and clearly.

\section{Strengths:}

$>$ Very detailed and very comprehensive assignments

$>$ Understanding the different issues in individual learning module

$>$ Very well structured

$>$ Excellent range of appropriate resources used.

\section{Weaknesses}

$>$ Grammatical error

$>$ Consider word count required for essay or report.

2. Read through all the feedback you have received from learning and teaching observations and summarise your strengths and weaknesses in terms of your practice as a teacher.

\section{Strengths:}

$>$ Subject knowledge

$>$ Clear planning and structure

$>$ Well organised handouts

$>$ Using useful variation in teaching strategies. Group dynamic strategy is developed well.

\section{Weaknesses}

$>$ Continue to develop alternative teaching strategies

$>$ Check spelling on handouts and white board

$>$ Timing need more effective development

3. Which development points have you addressed since recording your initial PDP?

\section{Personal:}

$>$ Interact well with learners

$>$ I aware of learners' abilities

$>$ I always praise and encourage students

$>$ I make the learners enjoy the lesson by linking the lesson to the real life. 


\section{Professional (teaching and learning):}

$>$ I prepare well for the session including handouts and lesson plan.

$>$ I do self-evaluation and reflection after each session

$>$ I use appropriate assessment methods such as exercises, quiz, Q/A and project t.

$>$ I use learners' feedback to inform future practice.

$>$ I link the current session to the previous sessions.

\section{General}

I consider learners' abilities when prepare session material and lesson plan. For example, I provide an easy exercise to implement each outcome. Also, I consider the time required to achieve each objective because my learners are ICT beginners and ESOL level.

How have you maintained/improved your subject expertise and up-dated your skills and knowledge I improved my subject expertise and knowledge by reading more relevant resources including books, articles and Web sites. I up-date my teaching skills by doing self-reflection and evaluation after finishing each lesson. I always use different teaching techniques in order to engage my learners and be motivated. 
Action Plan-Final Observation

\begin{tabular}{|c|c|c|c|c|}
\hline Development Need & Action Required & Resources/Support & $\begin{array}{c}\text { Evidence of } \\
\text { achievement will } \\
\text { be..... }\end{array}$ & Target Date \\
\hline $\begin{array}{l}\text { Grammar and } \\
\text { spelling errors in } \\
\text { handouts and white } \\
\text { board } \\
\text { Teaching } \\
\text { Strategies } \\
\text { Lesson Timing }\end{array}$ & $\begin{array}{l}\text { Check grammar and spelling } \\
\text { errors using spell check Tool } \\
\text { in Microsoft Word and } \\
\text { PowerPoint. } \\
\text { Prepare well and check the } \\
\text { spelling of each word before } \\
\text { writing them on the white } \\
\text { board } \\
\text { Use different teaching } \\
\text { strategies to engage the } \\
\text { students and be motivated. } \\
\text { Allocate the expected time } \\
\text { required to finish each } \\
\text { outcome on the lesson plan } \\
\text { by considering learners' } \\
\text { abilities. }\end{array}$ & $\begin{array}{l}\text { Spell check Tool in } \\
\text { Microsoft Word } \\
\text { Read relevant } \\
\text { resources using } \\
\text { books, Web sites and } \\
\text { PGDE handouts } \\
\text { Lesson plan. Read } \\
\text { books, articles, Web } \\
\text { sites about time } \\
\text { management. }\end{array}$ & Future career & Starting job \\
\hline
\end{tabular}

\section{References}

[1] Kelly, C., David Kolb, the theory of experiential learning and ESL. The Internet TESL

Journal, III, 9 September 1997, pp 1-6.

[2] Department for Innovation Universities and Skills (2007). A Guide to the Further Education

Teachers' Qualificationsn(England) Regulations 2007, Available at: http://www.dius.gov.uk/publications/guide2007no2264.pdf. 19/05/08.

[3] Francis, H., M. Clare, et al. (2007). "Individuality in Learning: A Guide to understanding and promoting Individual Learning."

[4] Krathwohl, D., "A Revision of Bloom's Taxonomy: An Overview." Theory Into Practice, vol. 41, No. (4): 2002, pp 212-218.

[5] Learning Theories Knowledgebase (2008). Maslow's Hierarchy of Needs, Available at: http://www.learning-theories.com/maslows-hierarchy-of-needs.html. 20/05/08. 
[6] Osterman and Kottkamp (1993). Reflective Practice, Available at: http://faculty.tamucommerce.edu/espinoza/ETEC625/978/shahid/.

[7] RTC (2003). Further Education Teacher Training Course, Available at: http://216.239.59.104/search?q=cache:LtvtTbSA7uYJ:www.questonline.co.uk/training ed ucation centres/rtc aldershot further education teacher training course+professional+ skills+and+personal+qualities+FE+teacher\&hl=en\&ct=clnk\&cd=1\&gl=uk. 20/05/08.

[8] Schneider, D. K. (2006). Reflection, available at: http://edutechwiki.unige.ch/en/Reflection\#Models of reflection.

[9] Schön, D. (1983). The Reflective Practitioner. How professionals think in action. London, Temple Smith.

[10] Schön, D. (1991). The Reflective Turn: Case Studies In and On Educational Practice. New York, Teachers Press, Columbia University.

[11] Smith, M. K. (2008). The Behaviourist Orientation toLearning, Available at: http://www.infed.org/biblio/learning-behavourist.htm. 20/05/08.

[12] Smith, M. K. (2008). Humanistic Orientations to Learning, Available at: http://www.infed.org/biblio/learning-humanistic.htm. 20/05/08.

[13] Sparks-Langer, G. M. (1992). In the eye of the beholder: Cognitive, critical and narrative approches to teacher reflection. Reflective Teacher Education: Cases and Critiques, Albany: State University of New York Press.: pp 147-160.

[14] UNICEF (2007). What Makes a Good Teacher?, Available at: http://www.unicef.org/teachers/teacher/teacher.htm. 7/3/08.

[15] Wallace, S. Teaching and Supporting Learning in Further Education, Learning Matters, 2001.

Eleyan, D. PhD in information systems, The University of Manchester, UK (2006). Hold a PGDE in Higher Education, Bolton University, UK (2008). He is assistant professor of Information Systems at Birzeit University Palestine. A member of the Academic Quality Committee, Published journal and conference papers in quality of education and information systems, supervised MSc thesis in proposing Academic quality system using balanced scorecard. Mr. Eleyan worked as a lecturer and course team leader of computing at South Essex College of Further and Higher Education, Essex, UK (2008). Mr. Eleyan is a member of the IFL (Institute for Learning UK), member of Higher Education Teaching and Learning Group and a member of Teaching Professors Group (Linkedln). 
Eleyan, A. PhD in Software Engineering, The University of Manchester, UK (2007). Hold a PGDE in Higher Education, Bolton University, UK (2008). She is now a lecturer at the computing school, Manchester Metropolitan University, UK. She was assistant professor of Software Engineering at Birzeit University Palestine for three years. A member of the Academic Quality Committee, Published journal and conference papers in quality of education and Software Engineering and web services, supervised BSc final year projects in webservices and computer engineering. Mrs. Eleyan worked as a lecturer and course team leader of Computer Networking at South Essex College of Further and Higher Education, Essex, UK (2008). Mrs. Eleyan is a member of the IFL (Institute for Learning UK), member of Higher Education Teaching and Learning Group and a member of Teaching Professors Group (LinkedIn). 